University of Michigan Law School

University of Michigan Law School Scholarship Repository

Law \& Economics Working Papers

$12-2-2017$

\title{
The Triumph of BEPS: US Tax Reform and the Single Tax Principle
}

Reuven S. Avi-Yonah

University of Michigan Law School, aviyonah@umich.edu

Follow this and additional works at: https://repository.law.umich.edu/law_econ_current

Part of the Law and Economics Commons, and the Tax Law Commons

\section{Working Paper Citation}

Avi-Yonah, Reuven S., "The Triumph of BEPS: US Tax Reform and the Single Tax Principle" (2017). Law \& Economics Working Papers. 142.

https://repository.law.umich.edu/law_econ_current/142

This Article is brought to you for free and open access by University of Michigan Law School Scholarship Repository. It has been accepted for inclusion in Law \& Economics Working Papers by an authorized administrator of University of Michigan Law School Scholarship Repository. For more information, please contact mlaw.repository@umich.edu. 


\title{
THE TRIUMPH OF BEPS: US TAX REFORM AND THE SINGLE TAX PRINCIPLE
}

\author{
Reuven S. Avi-Yonah \\ The University of Michigan
}

\begin{abstract}
The Tax Cut and Jobs Act (TRA17) as passed by the House on November 16 and by the Senate on December 2, 2017, contains multiple provisions that incorporate the principles of the OECD/G20 Base Erosion and Profit Shifting (BEPS) into domestic US tax law. Together with the changes in the 2016 model US tax treaty, these provisions mean that the US is following the EU and China in implementing BEPS and in particular its underlying principle, the single tax principle (i.e., all income should be subject to tax once: passive income at the residence state rate and active income at a minimum source tax rate). This represents a triumph for the G20/OECD and is incongruent with the generally held view that the US will never adopt BEPS.
\end{abstract}

\section{Introduction: The US and BEPS}

From 2013 to 2015, the US participated in the OECD/G20 effort to limit BEPS. However, until recently, the general view was that following the conclusion of the BEPS negotiations and the change of Administration the US is stepping back from the BEPS process. While the EU was charging ahead with implementing BEPS through the Anti-Tax Avoidance Directive (ATAD), the US stated that it was already in compliance with all BEPS minimum standards and therefore other than Country by Country (CBC) reporting it had no further BEPS obligations. The US refused to join the Multilateral Instrument (MLI) to implement BEPS into tax treaties, and did not join the common reporting standards (CRS) to further automatic exchange of information, leading the EU to call it a tax haven. The US did adopt BEPS provisions in its model tax treaty, but those have not been implemented in any actual US treaty. ${ }^{1}$ Thus, most observers believe that the US has abandoned the BEPS effort.

\footnotetext{
${ }^{1}$ On BEPS and the US Model see Avi-Yonah, Reuven S., Full Circle? The Single Tax Principle, BEPS, and the New US Model (October 13, 2015). U of Michigan Public Law Research Paper No. 480; 1 Global Tax'n 12 (2016); U of Michigan Public Law Research Paper No. 480; U of Michigan Law \& Econ Research Paper No. 15-019. Available at SSRN: https://ssrn.com/abstract $=2673463$ or http://dx.doi.org/10.2139/ssrn.2673463.
} 
But this view is wrong. The current tax reform legislation in both the House version (TRA17H) and Senate version (TRA17S) clearly relies on BEPS principles and in particular on the single tax principle. ${ }^{2}$ This represents a triumph for the G20/OECD and is incongruent with the generally held view that the US will never adopt BEPS.

\section{The House Bill (TRA17H)}

TRA17H has three BEPS related provisions: A tax on past offshore accumulations, a tax on future offshore accumulations, and a tax on base erosion payments to related parties.

\section{a. Past Accumulations.}

TRA17H, section 4004, imposes a 14\% tax on past accumulations of cash or cash equivalents, and $7 \%$ on illiquid assets, payable over eight years.

The accumulation of offshore profits by US multinationals in low tax jurisdictions has been the focus of significant concern and a primary driver of the BEPS effort. The EU ATAD and State Aid as well as the UK Diverted Profits Tax (DPT) and current discussion on the digital economy all reflect these concerns. The imposition of US tax on past profits is insufficient, because there is no policy rationale for not taxing these profits in full (since they have been earned, there is no competitiveness or neutrality argument). But given that most MNEs do not have a tax reserve for such payments on permanently invested income and their lobbying clout, this is the best that could be expected. The rate is similar to the proposed rate under President Obama and much higher that what the EU Commission has demanded from Apple in the State Aid context (Apple Ireland has $\$ 230$ billion, so $7 \%$ is $\$ 16.1$ billion, and since some of it is in cash the amount will be higher, while the EU demands $\$ 13$ billion). This is likely to moot the EU State Aid cases. ${ }^{3}$

\footnotetext{
2 For my overall view on TRA17H see Avi-Yonah, Reuven S. and Fishbien, Nir, Once More, with Feeling: The 'Tax Cuts and Jobs' Act and the Original Intent of Subpart F (November 20, 2017). Available at SSRN: https://ssrn.com/abstract=3074647; for TRA17S see Avi-Yonah, Reuven S., Guilty as Charged: Reflections on TRA17 (November 25, 2017). Available at SSRN: https://ssrn.com/abstract=3077342. ${ }^{3}$ For the Obama proposal see Avi-Yonah, Reuven S., All or Nothing? The Obama Budget Proposals and BEPS (February 16, 2015). U of Michigan Public Law Research Paper No. 442. Available at SSRN: https://ssrn.com/abstract=2565727 or http://dx.doi.org/10.2139/ssrn.2565727 and Avi-Yonah, Reuven S., Vive La Petite Difference: Camp, Obama, and Territoriality Reconsidered (April 4, 2012). U of Michigan Public Law Working Paper No. 267. Available at SSRN: https://ssrn.com/abstract=2034427 or http://dx.doi.org/10.2139/ssrn.2034427;
} 


\section{b. Future Accumulations}

TRA17H, section 4301, states that if a US parent corporation has "foreign high returns", defined as the aggregate return of its CFCs that exceeds 7\% plus the Federal short term rate on the CFCs aggregate adjusted bases in depreciable tangible property (the "trigger rate"), then it is subject to an immediate inclusion of $50 \%$ of its foreign high returns, i.e., an effective tax rate of $10 \%$, regardless of whether the earnings are repatriated.

This provision has several flaws. First, obviously $10 \%$ is better than $20 \%$ (the rate on domestic US income), and given the availability of the dividend exemption, there would be an incentive to shift profits in the knowledge that they can be repatriated at any time. Second, current foreign tax credits are available to offset the $10 \%$ tax, although only for $80 \%$ of foreign taxes paid. The effect will be to have no US tax due as long as the foreign tax rate is $12.5 \%$ (so that the foreign tax credit offsets $80 \%$ of $12.5 \%$, or $10 \%$ ), which is not coincidentally the official Irish rate, even if the trigger rate is zero (because there are no tangible assets offshore). Third, the trigger rate will shield some multinationals more than others. Ironically, the more tangible assets you have offshore, the higher your trigger rate, so companies like GE that actually make things offshore will do much better than companies like Microsoft, Google or Amazon. This will be an inducement to move jobs (not just profits) offshore.

In addition, TRA17H section 4301 will have another perverse effect- it will induce inversions. If a company successfully inverts, it will not be subject to the foreign high return inclusion, and will be able enjoy zero tax on those like under current law, as opposed to up to $10 \%$.

But it cannot be denied that this provision is a significant improvement over current law. Under current law the effective foreign tax rate of many US MNEs is close to zero. While this will still be true for some tangible intensive MNEs, the main BEPS culprits (Apple, Amazon, Microsoft, Google, Facebook, Netflix, Uber) will face a tax of $10 \%$ (since their trigger rate is zero), few foreign tax credits, and no possibility of inverting since most of them are controlled by founders subject to the shareholder level tax (Bill Gates, Sergei Brin, Larry Page, Mark Zuckerberg et al. will never agree to pay tax on their unrealized appreciation).

\section{c. Base Erosion}

on State Aid see Avi-Yonah, Reuven S. and Mazzoni, Gianluca, Apple State Aid Ruling: A Wrong Way to Enforce the Benefits Principle? (October 27, 2016). U of Michigan Law \& Econ Research Paper No. 16-024. Available at SSRN: https://ssrn.com/abstract=2859996. 
There are several inbound provisions in TRA17H that are supposed to prevent base erosion. For example, under section 3301, net interest in excess of $30 \%$ of EBITDA will not be deductible (TRA17S has the same rule for EBIT). This rule is necessary to prevent negative tax rates in conjunction with expensing (section 3101) and the active foreign dividend exemption (section 4001).

The other major inbound provisions are a limit on interest expense that does not allow the US subsidiary to be leveraged more than $10 \%$ over the leverage of its worldwide group (section 4302) (this is also in TRA17S) and a new excise tax of $20 \%$ on deductible payments other than interest paid by a US corporation to a related foreign corporation (section 4303). The excise tax can be avoided if the related foreign corporation chooses to treat the payments as ECI subject to $20 \%$ tax.

The excise tax is sure to initially enrage our treaty partners, who will see it as an indirect way to impose a withholding tax on royalties (contrary to article 12 of the tax treaties) as well as violating the arm's length standard of article 9 (because the excise tax applies to cost of goods sold between related parties, implying that it is inflated, regardless of what unrelated parties would have agreed upon). It may also be subject to a WTO challenge, although less than the TRA17S provisions discussed below. But it is definitely consistent with the spirit of BEPS, and eventually may be accepted and even copied by the EU and other countries. ${ }^{4}$

The main problem with the excise tax is that it only applies to deductible payments to related parties. An inverted multinational can sell as much as it wants directly to US customers or to unrelated US distributors and it will avoid the excise tax. But not all multinationals can invert, and this limit on the excise tax is similar to the UK and Australian DPTs, which also depend on the presence of domestic related parties. ${ }^{5}$

\section{The Senate Bill (TRA17S)}

${ }^{4}$ See Avi-Yonah, Reuven S., Constructive Unilateralism: US Leadership and International Taxation (June 25, 2015). U of Michigan Public Law Research Paper No. 463. Available at SSRN: https://ssrn.com/abstract $=2622868$ or http://dx.doi.org/10.2139/ssrn.2622868.

${ }^{5}$ On these taxes see Avi-Yonah, Reuven S., Three Steps Forward, One Step Back? Reflections on 'Google Taxes', BEPS, and the DBCT (May 24, 2016). U of Michigan Law \& Econ Research Paper No. 16-016; U of Michigan Public Law Research Paper No. 516. Available at SSRN: https://ssrn.com/abstract $=2783858$ or http://dx.doi.org/10.2139/ssrn.2783858. 


\section{a. Past Accumulations}

TRA17S taxes past accumulations at 14.5\% (cash) and 7.5\% (non-cash). This is even better than TRA17H and may be further improved in conference, as more revenue may be needed to fund other compromises (e.g., reinstating the deduction for state and local taxes to appease GOP representatives from high tax states).

\section{b. Future Accumulations}

For future Global Intangible Low Tax Income (GILTI), TRA17S provides that a U.S. shareholder of any CFC must include in gross income for a taxable year its GILTI in a manner generally similar to inclusions of subpart F income. GILTI means, with respect to any U.S. shareholder for the shareholder's taxable year, the excess (if any) of the shareholder's net "CFC tested income" over the shareholder's "net deemed tangible income return." The shareholder's "net deemed tangible income return" is an amount equal to 10 percent of the aggregate of the shareholder's pro rata share of the qualified business asset investment ("QBAI") of each CFC with respect to which it is a U.S. shareholder. "Net CFC tested income" means, with respect to any U.S. shareholder, the excess of the aggregate of its pro rata share of the tested income of each CFC over the aggregate of its pro rata share of the tested loss of each CFC. The tested income of a CFC means the excess of the gross income of the corporation determined without regard to certain exceptions (including the current active finance exception and the CFC look-through rule) over deductions (including taxes) properly allocable to such gross income. QBAI means, with respect to any CFC for a taxable year, the average of the aggregate of its adjusted bases, determined as of the close of each quarter of the taxable year, in specified tangible property used in the production of tested income in its trade or business and of a type with respect to which a deduction is generally allowable under section 167 .

The tax rate of future GILTI is determined by taking the US tax rate (20\%) and allowing a deduction of $50 \%$, or $10 \%$, for a net rate of $10 \%$. This rate can be partially offset by foreign tax credits, but in a separate basket (but with cross-averaging within the basket). The proposal is effective for taxable years of foreign corporations beginning after December 31, 2017.

What this means in plain English is that Amazon, Apple, Facebook, Google, Netflix, and their ilk will have to pay tax at $10 \%$ on future GILTI because they have CFCs that produce "tested income" (and no loss) in excess of $10 \%$ over their basis in offshore tangible assets, which is zero or close to it (since they derive almost all of their income from intangibles). Other MNEs (e.g., GE or Intel) will pay less because they have more tangible assets offshore. This creates an obvious incentive to move jobs 
(not just profits) offshore. In addition, the proposal standing on its own would also induce profit shifting because of the combination of the participation exemption and the lower rate (10\% is less than $20 \%)$.

To address these issues (which plague TRA17H), TRA17S proposes to apply a reduced rate of $12.5 \%$ to domestic GILTI derived from exports related to intangibles. Domestic GILTI is eligible for the $12.5 \%$ rate is "foreign derived intangible income," which is defined as the amount which bears the same ratio to the corporation's "deemed intangible income" as its "foreign-derived deduction eligible income" bears to its "deduction eligible income."

Deemed intangible income is the excess of a domestic corporation's deduction eligible income (gross income without regard to subpart $\mathrm{F}$ income, GILTI, and other enumerated categories) over its deemed tangible income return ( $10 \%$ of its $\mathrm{QBAI})$.

The "foreign-derived deduction eligible income" is defined as income derived in connection with (1) property that is sold by the taxpayer to any foreign person for a foreign use or (2) services to any foreign person or with respect to foreign property. In other words, this category comprises exports for property and services, although not royalty income received from foreigners.

Deduction eligible income is essentially the domestic corporation's modified gross income calculated without regard to subpart F and GILTI (as well as a few other enumerated categories). So a U.S. company's foreign derived intangible income, which gets the $12.5 \%$ rate, is the amount that bears the same ratio to the deemed intangible income as the U.S. company's exports bear to its modified gross income.

This "remedy" may be effective in partially addressing the shifting problem (although $12.5 \%$ is higher than 10\%), but the domestic GILTI provision has an obvious WTO problem: It is a subsidy contingent on export performance, which is explicitly banned by the Subsidies and Countervailing Measures (SCM) agreement. This was precisely the type of export subsidy struck down in the FSC and ETI cases, resulting in massive potential sanctions and forcing the US to repeal the subsidy and enact the ineffective and scheduled for repeal domestic manufacturing subsidy (section 199). I would expect that this provision will be struck down by the WTO, and the US will be left with only the foreign GILTI provision. As stated above, the foreign GILTI provision is inadequate, but this can be fixed by a future Democratic administration by setting the GILTI rate as the same as the domestic rate $(20 \%)$.

\section{c. Base Erosion}


The anti-base erosion proposal in TRA17S is in many ways an improvement over TRA17H. In TRA17S, there is no excise tax. Instead, US corporate taxpayers have to pay a "base erosion minimum tax" (BEMT), at $10 \%$ less any applicable credits (including the foreign tax credit, but the US taxpayer is unlikely to have them for the relevant income since any foreign tax is imposed on the foreign related party). The tax base is taxable income plus "base erosion payments", defined as any amount paid or accrued by a taxpayer to a foreign person that is a related party of the taxpayer and with respect to which a deduction is allowable, including interest (to the extent not otherwise disallowed) and, only for inverted corporations, also cost of goods sold. Withholding taxes (if any) are allowed as an offset. There is a safe harbor for smaller corporations with gross receipts below $\$ 500$ million and another for base erosion payments of less than $4 \%$. The proposal applies to base erosion payments paid or accrued in taxable years beginning after December 31, 2017.

Formally, this proposal does not raise the same treaty issues as TRA17H, because the BEMT is applied only to the US party, so that the savings clause applies (US tax treaties Art 1(4)), and there is no forced ECI election. Still, it is likely that our trading partners will not view this provision favorably, since it appears substantively to be a violation of article 11 (no withholding on interest), 12 (no withholding on royalties), 9 (no denial of deduction for cost of goods sold if it is equivalent to the arm's length price), and 24 (no discrimination in denying deductions). They are likely to retaliate by imposing tax on the royalties or cost of goods sold without a credit for the BEMT, and that will result in double taxation since there is no reverse FTC provision in TRA17S (unlike TRA17H). But as stated above, this provision is consistent with the spirit of BEPS, and may eventually be found acceptable.

\section{c. Anti-Hybrid Provisions}

TRA17S contains two anti-hybrid provisions that directly implement the single tax principle, similarly to the ATAD. The first, section 14101, IRC $245 \mathrm{~A}(\mathrm{e})$, disallows the participation exemption for hybrid dividends that are treated as deductible payments at source. The second, section 14223, limits the deductibility of payments on hybrid instruments or to hybrid entities. These provisions clearly implement OECD BEPS Action 2 in accordance with the single tax principle.

It may seem strange that the US takes this action while making the CFC to CFC look through rule (IRC 954(c)(6)) permanent and thereby facilitating profit shifting from high to low tax jurisdictions abroad. But this is perfectly consistent with the spirit of BEPS: The US will tax at residence if 
there is no tax at source and will tax at source if there is no tax at residence, but it will not impose tax where both source and residence are foreign- that is left to the foreign jurisdictions to resolve by adopting their own anti-BEPS rules, like the ATAD.

\section{Conclusion: The Future of BEPS}

I believe that with the expected final passage of TRA17, the future of BEPS as the underlying standard of the international tax regime (ITR) is assured. As long as the US stood aside, it was not clear that the EU could implement BEPS on its own, and China is just beginning to adopt BEPS measures. ${ }^{6}$ But TRA17 in both versions represents the incorporation of BEPS into US domestic tax law. It turns out that the immense effort of the OECD in 2013-15 was not in vain, and a new and better ITR is on the horizon.

${ }^{6}$ Avi-Yonah, Reuven S. and $\mathrm{Xu}$, Haiyan, China and the Future of the International Tax Regime (October 21, 2017). U of Michigan Law \& Econ Research Paper No. 17-017; U of Michigan Public Law Research Paper No. 572. Available at SSRN:

https://ssrn.com/abstract=3056796. 